\title{
Interaction Study, Synthesis and Characterization of Molecular Imprinted Polymer Using Functional Monomer Methacrylate Acid and Dimethylamylamine as Template Molecule
}

\author{
Studi Interaksi, Sintesis dan Karakterisasi \\ Molecular Imprinted Polymer Menggunakan Monomer \\ Fungsional Asam Metakrilat dan Dimetilamilamin sebagai \\ Molekul Template
}

\author{
Saeful Amin ${ }^{1,2 *}$, Sophi Damayanti ${ }^{1}$, and Slamet Ibrahim ${ }^{1 *}$ \\ ${ }^{1}$ School of Pharmacy, Bandung Institute of Technology, Jl. Ganesha No. 10 Bandung, Indonesia. \\ ${ }^{2}$ Program Study of Pharmacy, STIKes Bakti Tunas Husada Jl. Cilolohan 36 Tasikmalaya, Indonesia.
}

Submitted 7 Desember 2017, Acceptance 25 Januari 2018

\begin{abstract}
The research related to the interaction study, synthesis and characterization of molecular imprinted polymer using dimethylamylamine (DMAA) as the template molecule and the functional monomer methacrylate acid has been conducted. Molecular Imprinted Polymer (MIP) is a separation method made by the molecule template in the polymer matrix followed by removing the template molecule by washing for giving the permanent framework groove. The MIP was made by mixing the DMAA as the template molecule, with the methacrylate acid as the functional monomer, and the ethylene glycol dimethacrylate (EGDMA) as the crosslinker with ratio of 1:6:20. Porogen solvents used were the chloroform and the initiator azobisisobutyronitrile (AIBN). The crystal MIP and the NIP without the DMAA were characterized using Infrared Spectrophotometer (FTIR), and the result showed that there have been differences among the MIP, the NIP and the MIP after being extracted. The characterization using Scanning Electron Microscope (SEM) showed that the NIP as the comparison having flat morphology, while the MIP having irregular morphology and less pores. Then the MIP after being extracted has irregular, rough morphology and a lot of pores. The result reveals the interaction between the DMAA and the methacrylate acid that is the hydrogen bonded with the Gibbs free energy obtained is $-5.434 \mathrm{j} / \mathrm{mol}$. The imprinting factor of 2,353 is obtained. The highest desorption descending capacity is chloroform with the MIP $738 \%$ better. For the MIP and NIP methanol, it is found that the MIP is $123 \%$ better. Then the MIP which is desorbed by the chloroform is better $602 \%$ than the MIP resorbed by the methanol, and the ethyl acetate cannot desorb the DMAA.
\end{abstract}

Keywords: DMAA, MIP, SEM, FTIR, Gibbs free energy.

\begin{abstract}
Abstrak: Penelitian terkait dengan studi interaksi, sintesis dan karakterisasi molecular imprinted polymer menggunakan dimetilamilamin (DMAA) sebagai molekul template dan asam monomer metakrilat fungsional telah dilakukan. Molecular Imprinted Polymer (MIP) adalah metode pemisahan yang dibuat oleh template molekul dalam matriks polimer diikuti dengan menghapus molekul template dengan mencuci untuk memberikan alur kerangka permanen. MIP dibuat dengan mencampur DMAA sebagai molekul template, dengan asam metakrilat sebagai monomer fungsional, dan etilen glikol dimetakrilat (EGDMA) sebagai pengikat silang dengan rasio 1:6:20. Pelarut-pelarut porogen yang digunakan adalah kloroform dan inisiator azobisisobutyronitrile (AIBN). Kristal MIP dan NIP tanpa DMAA dikarakterisasi menggunakan spektrofotometer infra merah (FTIR), dan hasilnya menunjukkan bahwa ada perbedaan antara MIP, NIP dan MIP setelah diekstrak.
\end{abstract}

*Correspondence Author, Hp : 085723147090

Email: saeful_amin@stikes-bth.ac.id and sibrahim@fa.itb.ac.id 
Karakterisasi menggunakan Scanning Electron Microscope (SEM) menunjukkan bahwa NIP sebagai pembanding memiliki morfologi datar, sedangkan MIP memiliki morfologi tidak teratur dan sedikit pori-pori. Kemudian MIP setelah diekstraksi memiliki morfologi yang tidak teratur, kasar dan banyak pori-pori. Hasilnya mengungkapkan interaksi antara DMAA dan asam metakrilat yang merupakan ikatan hidrogen dengan energi bebas Gibbs yang diperoleh adalah $-5,434 \mathrm{j} / \mathrm{mol}$. Faktor imprinting diperoleh nilai 2,353. Kapasitas penurunan desorpsi tertinggi adalah kloroform dengan MIP $738 \%$ lebih baik. Untuk MIP dan NIP metanol, ditemukan bahwa MIP adalah 123\% lebih baik. Kemudian MIP yang diserap oleh kloroform lebih baik $602 \%$ daripada MIP yang diserap oleh metanol, dan etil asetat tidak dapat menghilangkan DMAA.

Kata kunci: DMAA, MIP, SEM, FTIR, energi bebas Gibbs.

\section{INTRODUCTION}

ACCORDING to United Nations Education, Scientific and Cultural Organization (UNESCO), sport is a physical activity such as games including the fight against the elements of nature, other people or oneself. Atheletes consume supplements to maintain the stamina. The consumed supplement is not only to maintain the stamina, but also to be used as doping. Doping is drugs which can influence the body condition, such as stamina, muscle strength or weight, which violate the competitive value of sport ${ }^{(1)}$.

The most highly used type of stimulant compounds is dimethylamylamine (DMAA) with 76 cases or 16, and commonly found in the food supplements ${ }^{(2)}$. The DMAA gives the disadvantageous side effects. The use of it without dosage will narrow the blood vessel and the artery so that it will increase the blood pressure and cause cardiovascular disease.

Molecular imprinted polymer (MIP) is a technique to produce a polymer having the cavity due to the disposal of the templates, in which the cavity serves to recognize the molecules of the same size, structure, chemical and physical properties. The selectivity and affinity of the templates itself will increase, while the concentration value is increasing ${ }^{(3)}$. Nowadays, the MIP methods are still being developed. Besides it is easy to be used in making polymers, it also costs low and there has been wide usage on many target molecules, both as chemical and biological elements such as drugs ${ }^{(4)}$.

Based on the background above, The aim of research are conduct the MIP for the DMAA compound analysis with the ratio of 1:6:20, then the formed MIP is characterized by using Fourier Transform Infra Red (FTIR) and Scanning Electron Microscopy (SEM) to find out the polymer complexes formed and the morphological form of the MIP. The MIP formed then was analyzed by using High Performance Liquid Chromatography (HPLC) to know the amount of the DMAA, the adsorption capacity, and the adsorption condition found in the MIP.

\section{MATERIAL DAN METHODS}

MATERIALS. The materials used in this research were the template of dimethylamilamin DMAA compound from sigma-Aldrich, methacrylate acid, ethylene glycol dimethacrylate (EGDMA) from Sigma-Aldrich, $\mathrm{KBr}$, and chloroform $\left(\mathrm{CHCl}_{3}\right)$.

Instruments. The hardware is a personal computer with the specification of Intel ${ }^{\circledR}$ core TM i3-4030U CPU@1.90GHz 1.90GHz, 6.00 GB RAM, and the softwares used were MarvinSketch, and Gausian. Besides, it also used Fourier Transform Infra Red (Jasco FTIR 4200), Scanning Electron Microscope (JEOL JSM-6510), UV-Vis Spectrophotometry High Performance Liquid Chromatography (Agilent Technologies 1120 Compact LC), oven (Memmert), analytical balance (Melter Toledo), sonicator, vortex, reagent bottle, funnel, micropipette, spatula, mesh 60 and 80 glass tools commonly used in pharmaceutical laboratory analysis.

METHODS. Preparation of the Compound Test. The compound test used was the DMAA, and the monomer used was methacrylic acid drawn its structure with the ChemDraw 2D manually. Then it was opened with ChemDraw 3D and the minimize energy was applied. Save it in the extension file sm2. $3 \mathrm{D}$ creation result is opened in MarvinSketch then it was saved in mol2 form.

Interaction Preparation. Open Pyrex application then make the methacrylate acid as the ligand and the DMAA as its macromolecule. Extract the file with mol extension then run vina.

Interaction Analysis. Open the Autodock tool then klick on docking, open Autodock vina result. Choose the out.pdbqt extension then choose the analysis and open the macromolecule on the pdbqt extension. Look at the hydrogen bond between the DMAA and the methacrylate acid.

See the energy occurs in the result of hydrogen bond screening by using Gaussian View 5.0.8 then the running optimization calculation was conducted using B3LYP Density Funtional Theory (DFT) method with 
the base set 6-311G and Gaussian 09W.

MIP Synthesis Using DMAA as Template

Molecule. The MIP synthesis was conducted by using bulk method while the DMAA was as the template molecule, functional monomer, the ethylene glycol dimethacrylate (EGDMA) as the cross linker, the azobisisobutyronitrile (AIBN) as the initiator and chloroform as the porogen solvent. The comparison used between the DMAA, the functional monomer, and the EGDMA was 1:6:20 (in mol) while the initiator was $0.8 \mathrm{~mL} / \mathrm{gram}$.

The DMAA was dissolved in the chloroform in the reagent bottle then it was synthesized for 15 minutes. The functional monomer was added to the reagent bottle then the sonication was applied for 30 minutes. Add the EGDMA and do the sonication for 5 minutes. Add the AIBN and do the sonication again for 15 minutes. Flow the nitrogen gas to the mixture in the bottle for 5-15 minutes then close the bottle cap and heat it using oven at the temperature $60{ }^{\circ} \mathrm{C}$ for 7 hours. Observe the crystals formed every 30 minutes. If crystal was formed, it was then sieved using mesh 60 and 80.

Non Imprinted Polymer (NIP) Synthesis. The NIP was synthesis as the comparator. The NIP was synthesized as the same composition and method as the MIP synthesis, but the DMAA as the template molecule was not added to the NIP.

Release of Template Molecule. The release of the template molecules was conducted by extracting the DMAA from the MIP. The extraction process was carried out by $200 \mathrm{mg}$ MIP input in the bottle and then it was dissolved in $10 \mathrm{~mL}$ of chloroform. Cover the bottle and do the sonication for 30 minutes. The process succeeds when the DMAA is extracted completely and being analyzed using FTIR.

Characterization ofMIP and NIP with FTIR. The MIP DMAA before extraction, the MIP DMAA after extraction and the NIP was characterized using FTIR. Sample preparation was completed by using $\mathrm{KBr}$ pellet method in which the powdered sample and the $\mathrm{KBr}$ mixed with 1:9 ratio and grinded to be homogeneous. After it was added into the template disc, it was compressed at 20 Psi pressure. The disc was installed on the holder then analyze with the FTIR.

Scanning Electeron Microscopy (SEM). The MIP and the NIP were characterized using the SEM by sticking the samples to the specimen holder then it was cleaned by the hand blower. The thin layer was given to the cleaned samplewith the gold paladitum then it was inserted into the specimen chamber and analyzed at 10000x and 25000x enlargements.

DMAA Standard Calibration Curve Manufacturing in the Chloroform. The DMAA dilution sequences in the chloroform with the concentrations $600,500,400,300,200$ and 100 ppm were prepared by piping from the $1000 \mathrm{ppm}$ DMAA parent solvent into the $20 \mathrm{~mL}$ muzzle flask. Add the chloroform to the boundary mark then homogenize. Read the AUC using the HPLC then create a calibration curve between the concentration (ppm) and the AUC. The equation of the line was determined as well as the equation of the linear regression.

Determination of Adsorption Capacity. Create the DMAA solvent in the chloroform with various concentrations of $600,500,400,300,200$ and $100 \mathrm{ppm}$. Put $5 \mathrm{~mL}$ of solvent from the various concentrations into $50 \mathrm{mg}$ NIP and MIP in the separate container. It was then incubated for 24 hours at room temperature. It was filtered and the supernatant was measured using the HPLC to see the concentration of the DMAA left in the solvent. The adsorption curve between the adsorbed amount and the initial DMAA concentrations were created. IF is calculated using the equation: $I F=\frac{A U C M I P}{A U C N I P}$

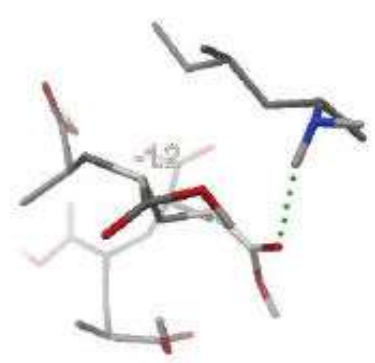

Figure 1. The screening of the hydrogen bond.

MIP Desorption Capacity and NIP of Various Solvents. Satu ml of chloroform solvent, ethyl acetate, methanol were added into each of the MIP and the NIP adsorption capacities results. The sonication was applied for 25 minutes. The mixture was filtered and the AUC filtrate at the DMAA wavelength was measured. The curve between the numbers of the released DMAA every $10 \mathrm{mg}$ of polymer toward the concentrations of the used DMAA was created.

\section{RESULT AND DISCUSSION}

Screening of Hydrogen Interaction. The screening of the hydrogen interactions was carried out to determine the occurrence of the hydrogen bond between the DMAA and the methacrylic acid. The interaction result was viewed by using the Autodock Tools application so that the interaction of the hydrogen bond between the DMAA and the metacrylic acid can be seen in Figure 1.

From the Figure 1 it can be seen, for the complex 
DMAA-polymethacrylate, the composition 6 has the hydrogen bond between $\mathrm{H}$ atom of the DMAA with carbonyl groups in atom $\mathrm{C}$ number 3 in polymethacrylate. In the DMAA structure, there are two $\mathrm{H}$ atoms that have electropositive, because they are bound to $\mathrm{N}$ atom that have high electronegativity, so that $\mathrm{H}$ atoms have an opportunity to interact to form the hydrogen bond. The hydrogen bond of the complex DMAA and the metacrylic acid monomer was $2.184 \AA$.

Analysis of Template, Functional Monomer and Template-Monomer Complex. The screening results will be obtained where the hydrogen bond occurs and then the template, monomer, and template-monomer complex are analyzed. The calculations of geometry and frequency optimizations were conducted using the Gaussian $09 \mathrm{~W}$. The geometry optimization is conducted to obtain the most stable form of the molecule. The geometry optimization of the molecule ignores the vibrational effects that are the result of the motion between atoms, so that the vibrational effects occurring on the molecule are completed by the frequency calculation.

The frequency calculations are performed to obtain the results of the thermal correction value of the total enthalpy energy and the entropy system as the reference for the calculation of Gibbs free energy. The calculations of geometry and frequency optimizations between the DMAA and the methacrylic acid were conducted using B3LYP density Functional Theory (DFT) method with base set 6-311G.

The template, functional monomer and complex

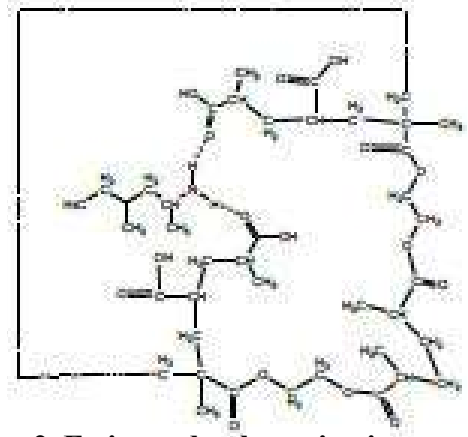

Figure 2. Estimated polymerization structure.

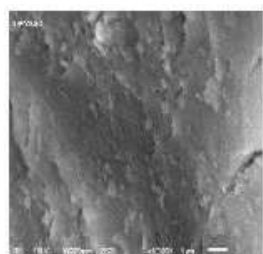

a

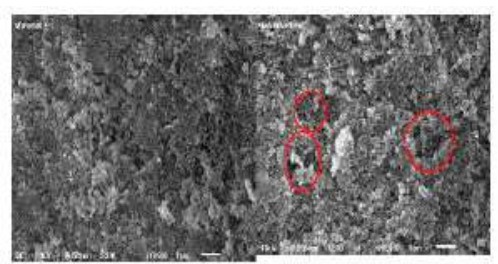

b
Figure 3. Polymer morphology obtained by using Scanning Electron Miscroscop on the NIP Crystal (a), the MIP (b), the MIP without the DMAA (c) in 10.000x enlargements.

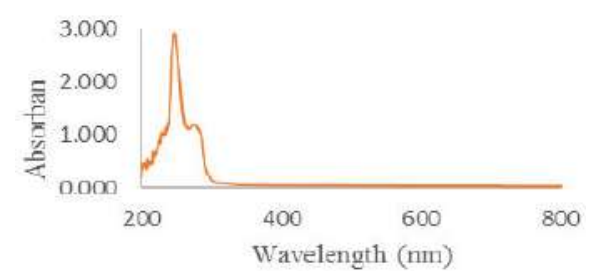

Figure 4. Maximum DMAA wavelength measurement graph.

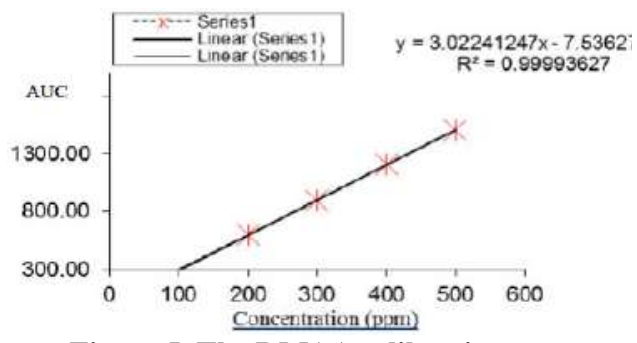

Figure 5. The DMAA calibration curve.

template-functional monomer between the DMAA and the methacrylic acid (through screened hydrogen bonds) were each manually created in the complex GaussianView 5.0.8. that has been drawn in clean to get in the best position. The calculation was completed in the Gaussian 09W.

The binding energy between the DMAA complex and the methacrylic acid is $-9026.28 \mathrm{kcal} / \mathrm{mol}$. The smaller the binding energy, the stronger is the interaction energy. The more stable the complex formed, the better the selectivity of MIP in the can could be. However if the interaction is too strong, it will be difficult when the DMAA removal process has to go through the special treatment in the washing, such as, heating during removal. When the large binding energy exhibits the poor interaction and less complex stability between template and functional monomer, the resulted MIP has low selectivity.

The Gibbs energy obtained must be negative so that the reaction runs spontaneously. In the computational results of the complex DMAA and methacrylic acid of $1: 6$, it is obtained the value of Gibbs energy $-9086.792 \mathrm{kcal} / \mathrm{mol}$. The small value of Gibbs free energy indicates that the conformation formed is stable ${ }^{(11)}$. Based on the calculation of equilibrium constant value $(\mathrm{K})$ of the complex, it is obtained that the value is $\mathrm{K}=9.638092$ ). The reaction is said to occur spontaneously if the value of $K>1$ or better $>>1$. The greater the value of $\mathrm{K}$ in the complex, the better is the spontaneity of the reaction.

Synthesis of MIP and NIP. In this research, the method used is bulk method because it is quite simple and does not require any special instrument or skill in its manufacture. The products obtained from the synthesis process require the grinding and the sieving before use. The components used in the manufacture 
of the MIP involved the methacrylic acid monomers, the EGDMA, the DMAA, and the AIBN. The occurred interaction is the non-covalent bond that occurs on the side of the MIP bond. The non-covalent bond is widely used because the ease of extracting the templates in this case is the DMAA, contrast to covalent bond. In the covalent bond, it requires more difficult extraction process of non-covalent interactions.

The DMAA used as the template is the compound which is going to be analyzed. The functional monomer used is methacrylic acid which acts as the functional group provider responsible for interacting with the template especially the $\operatorname{DMAA}^{(6)}$.

The initiator used was azobisisobutironitril (AIBN). The AIBN forms free radicals by the heating at the temperature of $60{ }^{\circ} \mathrm{C}-70{ }^{\circ} \mathrm{C}$. In the synthesis process, the polymerization reaction by the AIBN initiator occurs. The double bond will be split and there will be long molecular combinations. The polymerization reaction takes place through four stages: decomposition, initiation, propagation, and termination ${ }^{(7)}$. The initiation stage is the monomer activation reaction before starting the polymerization process then the monomer with the end of the reactive chain will under go the propagation reaction and will continue until the termination reaction occurs. The cross linker used was ethylene glycol dimethacrylate (EGDMA). The EGDMA is one of the most widely used crosslinkers in the MIP. The EGDMA synthesis used as the crosslinker because it can produce polymers that have good thermal and mechanical stability ${ }^{(3)}$. The crosslinker play a role in controlling the morphology of the polymer matrix, stabilizing the sides of the bond and maintaining mechanical stability. The large numbers of crosslinkers allow the cavity to maintain well its morphology or functionality ${ }^{(8)}$.

The interaction between the template and the monomer is an equilibrium process so as to shift towards the formation of the monomer-templates complex, the amount of monomer was added excessively ${ }^{(6)}$.

The vortex and sonication are applied to each of additional compound components for the introduction of the compound, so that it will dissolve completely. The nitrogen gas is flown to the mixture in the bottle for 5-15 minutes aims at removing the oxygen so that there will be no oxygen trapped in the formed MIP crystals. If the oxygen is found, it will form a cavity that is not created due to the interaction of the MIP composition but because the oxygen bubbles will reduce the MIP selectivity. Then the oxygen can slow the occurrence of polymerization by forming peroxide produced from the reaction between the oxygen with the free radicals formed. The heating was conducted for 7 hours using oven with the temperature $60^{\circ} \mathrm{C}$.

The oven heating has some advantages in the heating process the temperature will be stable, it is practical, and it faster than the water bath. The NIP is made as the comparison, weather the MIP synthesis is created well or not. The NIP was synthesized with the same number and condition as the MIP. However in the NIP process, the DMAA as the template was not added.

Organoleptically, the MIP from the synthesis is in the form of white yellowish crystal solid while the NIP is white.

Release of DMAA from MIP. The MIP crystals containing the DMAA inside was then extracted to remove the DMAA. The removal of the DMAA or the template molecule is an important process that can affect the work of the MIP. The extraction process uses the sonication methods because it is easy and gives a slight effect to the MIP. The sonication aims to get the DMAA completely off from the MIP.

The result of this DMAA removal from the MIP will give an empty gap which was originally filled by the DMAA.But because its DMAA is extracted, it will produce a cavity. The result of this removal is expected to have the high selectivity to retain the DMAA residing in the sample that will be analyzed specifically for the DMAA. The removal process is quite important and should be conducted very carefully as the number of cavities produced will affect how many analytes can be tied to the polymer ${ }^{(9)}$.

Characterization of MIP and NIP Morphology with SEM Instrument. In the NIP, the SEM resultis obtained. Its morphology is very different from the MIP or the MIP without the DMAA for the NIP having the flat or smooth shape, and no cavityat all. The regular NIP structure indicates no specific binding sites are formed by the template, whereas the cavity formed on MIP is due to the printed template molecule.

Determination of Wavelengths from DMAA Using Spectrophotometry. The determination of the DMAA wavelength was conducted by dissolving the DMAA in the chloroform thenits maximum wavelength in the range of $200-800 \mathrm{~nm}$ was measured. In the measurement of the DMAA maximum wavelength, the wavelength of 248 is obtained.

Preparation of DMAA Calibration Curve. The calibration curve is a line obtained from the points stating a concentration of absorbed absorbance after the linear regression analysis is conducted. The calibration curve is used to determine the adsorption and desorption capacity. In the preparation of calibration curve, various concentration series, 100, 200, 300, 400, and $500 \mathrm{ppm}$ were applied. Analysis for the calibration curve preparation uses the HPLC with 
the flow rate $0.6 \mathrm{ml} / \mathrm{min}$ and eluen acetonitrile: water.

The linear equation obtained, i.e. $\mathrm{y}=3.022 \mathrm{x}-$ 7.536 with the regression coefficient $(\mathrm{R} 2)$ of $=0.9999$ indicates the existence of the high linearity line.

Characterization of MIP and NIP Using FTIR. The FTIR spectrum between the MIP and DMAA has several peaks that have similarities. In the absorption area $3471 \mathrm{~cm}^{-1} ; 2962 \mathrm{~cm}^{-1} ; 2962 \mathrm{~cm}^{-1} ; 1589 \mathrm{~cm}^{-1}$; $1465 \mathrm{~cm}^{-1}$. The absorption occurring in the region of $3500-3400 \mathrm{~cm}^{-1}$ is an amine group $\left(\mathrm{NH}_{2}\right)$ of uptake at the wave number $2962-2872 \mathrm{~cm}^{-1}$ which is the methyl group $\left(\mathrm{CH}_{3}\right)$, the absorption at the wave number 1650$1560 \mathrm{~cm}^{-1}$ is $\mathrm{NH}$, the absorption in wave number $1470-1430 \mathrm{~cm}^{-1}$ represents the $\mathrm{CH}_{2}$. The spectrum similarity between the DMAA and the MIP contained shows that the DMAA has been perfectly polymerized into functional monomer and the MIP synthesis is successful ${ }^{(10)}$.

The characterization is conducted on the NIP, the MIP, and the MIP without the DMAA. The polymerization occurred perfectly which is indicated by the occurrence of $\mathrm{C}=\mathrm{O}$ carboxylate groups at 1727 $\mathrm{cm}^{-1}$ are of the NIP, the MIP, and the MIP without the DMAA indicating the occurrence of methacrylic acid in crystals which can be seen in Figure 7. The methacrylic acid used as the monomer is the carboxylic acid group, which has the typical and predominant $\mathrm{C}=\mathrm{O}$ absorption at the wave number $1780-1650 \mathrm{~cm}^{-1}$. The vinyl group of methacrylic acid will give the twin powder uptake in the area of about $1000 \mathrm{~cm}^{-1}$. The absence of the uptake area indicates that polymerization has occurred perfectly ${ }^{(9)}$.

The FTIR data is required to ensure all DMAAs have been released. If the DMAA are released then the FTIR MIP spectrum without the DMAA and the NIP will be the same, both from the functional area and fingerprint area ${ }^{(10)}$.

In Figure 8 the FTIR MIP spectrum without the DMAA has been similar to the FTIR NIP spectrum in both the functional group and the fingerprint area with the characteristic MIP without the DMAA and the NIP is not more pointed than the MIP. At the wave number 1153, the MIP valley is more pointed because

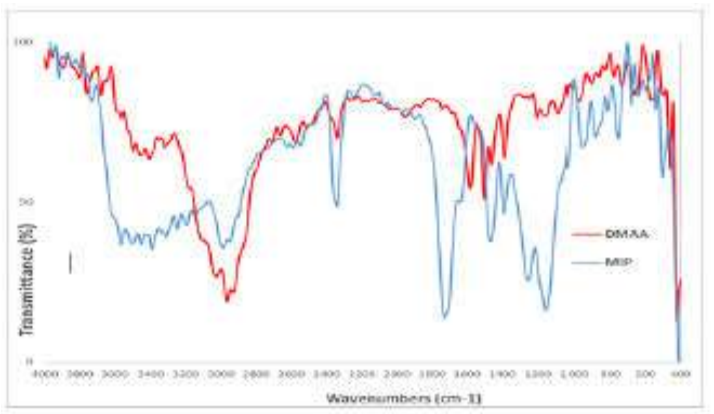

Figure 6. FTIR DMAA and MIP spectrums.

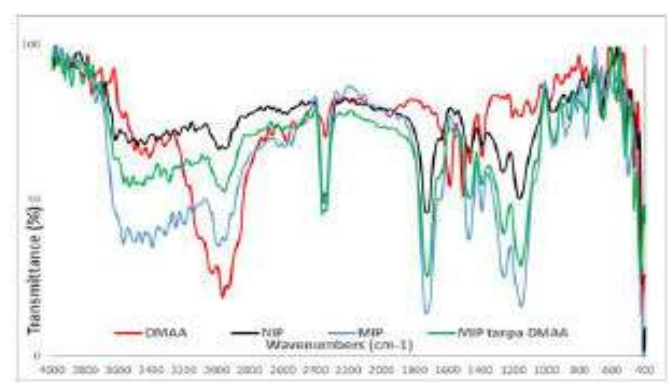

Figure 7. FTIR spectrums of the DMAA crystal, MIP, NIP and MIP without the DMAA.

there is the energy from the DMAA that encourages $\mathrm{CN}$ groups then the coupling in this area formed due to the occurrence of hydrogen bonds. In the MIP without the DMAA and the NIP, the absorption at

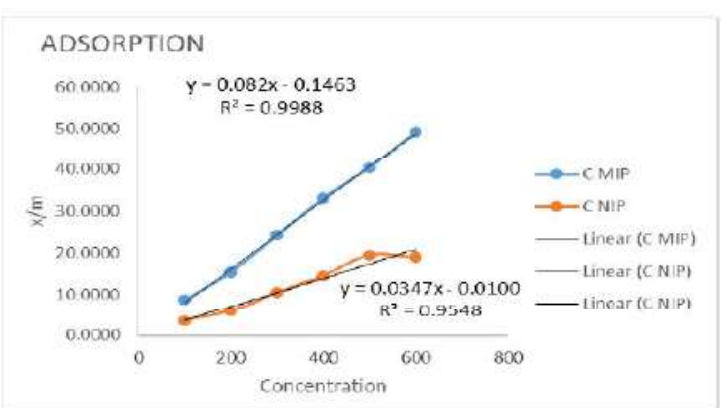

Figure 8. Chloroform adsorption curve.

$3448 \mathrm{~cm}^{-1}$ does not occur which is the $\mathrm{NH}$ absorption indicating the occurrence of the DMAA. In the MIP and the Comparator DMAA have similar absorption peak at $3448 \mathrm{~cm}^{-1}$ area because the NH occurs equally. This shows that DMAA has been polymerized into the functional monomer and the MIP synthesis is successful.

Determination of Adsorption and Desorption. The determination of adsorption capacity is conducted to see the MIP's ability to bind the DMAA. In determining the adsorption capacity of the chloroform solvent, since the good solvent in binding the template molecule is the solvent used in the polymerization, the adsorption capacity determination is conducted by the batch method, which sonication is applied for the introduction of the DMAA to the cavities contained in the MIP polymer. Then incubate for 24 hours. The solvent is filtered. Each filtrate with different concentrations of 100 ppm, 200, 300, 400, 500 , and $600 \mathrm{ppm}$ its AUC were measured by using high performance liquid chromatography (HPLC). The eluent used was acetonitrile-water 9:1 for 10 minutes at the flow rate $0.6 \mathrm{~mL} / \mathrm{min}$ flow.

Figure 8 shows the MIP and the NIP adsorption curves with the area values under the MIP and the NIP 


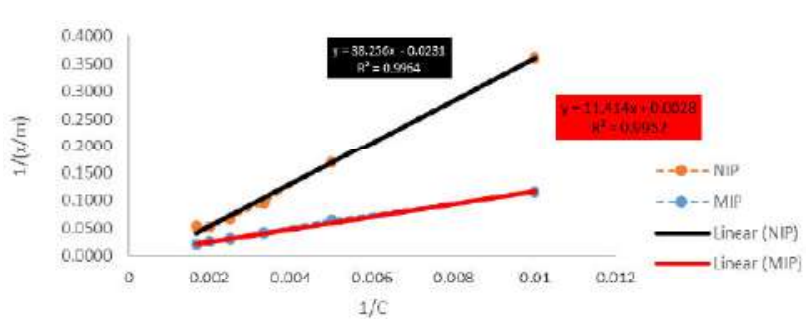

Figure 9. Langmuir isothermal adsorption model.

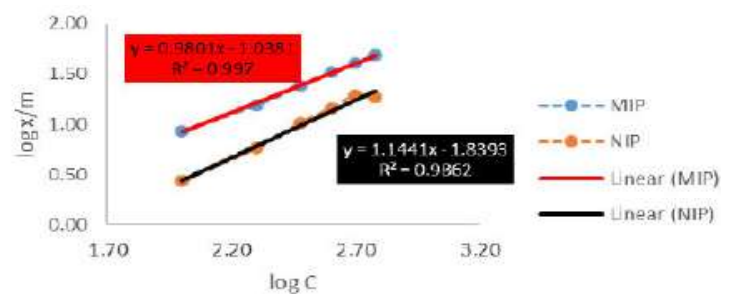

Figure 10. Freundlich isothermal adsorption model.

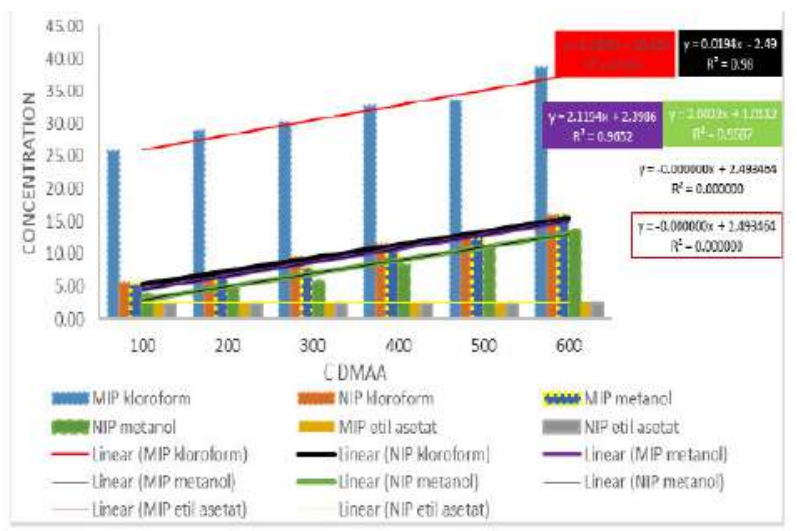

Figure 11. Curve total of the desorbed MIP and NIP toward DMAA concentration.

curves respectively 14276.85 and 6067.5. Imprinting factor is calculated by comparing the MIP distribution coefficients with NIP or comparing the area under the MIP curve with the area under the NIP curve, then the result obtained is 2.353 . The MIP cavity has an affinity for the rated molecule if IF is more than 1 , so the MIP that has been made in this study is able to bind the template higher than the NIP (Manihuruk, 2017).

The adsorption mechanism of the MIP and the NIP can be determined by isotherm adsorption, i.e. with Langmuir and Freundlich models. The adsorption model of Langmuir on the adsorbat usually occurs only in the single surface area (monolayer), then it assumes that each adsorption side has the same affinity for the template molecule. Each atom is adsorbed at the specific location on the surface of the adsorbent. Each part of the surface can hold only one molecule or atom ${ }^{(5)}$.

Freundlich isotherm adsorption model is often used to describe the adsorption of organic and inorganic compounds in the solvent. The assumption of this isotherm is based on the heterogeneous surface
Table 1. Langmuir equation.

\begin{tabular}{lcccc}
\hline Polymer & \multicolumn{4}{c}{ Langmuir } \\
\cline { 2 - 5 } & $\mathbf{R}^{2}$ & $\boldsymbol{\alpha}$ & $\boldsymbol{\beta}$ & $\Delta \mathbf{G}(\mathbf{j} / \mathbf{m o l})$ \\
\cline { 2 - 5 } MIP & 0.0996 & 0.087 & 0.0002 & -20.595 \\
\multirow{2}{*}{ NIP } & 0.9952 & 0.026 & 0.0006 & -18.364 \\
\hline
\end{tabular}

Table 2. Freundlich equation.

\begin{tabular}{lcccl}
\hline Polymer & \multicolumn{4}{c}{ Freunlich } \\
\cline { 2 - 5 } & $\mathbf{R}^{2}$ & $\mathbf{n}$ & $\mathbf{K}$ & \multicolumn{1}{c}{$\Delta \mathbf{G}(\mathbf{j} / \mathbf{m o l})$} \\
\cline { 2 - 5 } MIP & 0.997 & 0.974 & 10.917 & -5.922 \\
NIP & 0.986 & 1.047 & 69.072 & -10.492 \\
\hline
\end{tabular}

with several types of active adsorption centers ${ }^{(5)}$.

The equation used is the equation with the greatest $\mathrm{R} 2$ value. The largest comparison of Langmuir and Freundlich R2 values is Langmuir. The assumption of this isotherm is based on the occurrence of the homogeneous surface with several types of active adsorption centers ${ }^{(5)}$.

The desorption is conducted by using different solvents with different polarity. The solvents used are chloroform, ethyl acetate and methanol. The chloroform is the porogen solvent which is used at the time of MIP and NIP synthesis.

From the Figure 11, it is possible that the results of ethyl acetate cannot desorb the DMAA. The chloroform has the highest dissolved concentration value compared to the methanol and ethyl acetate. The MIP AUC chloroform with the NIP chloroform respectively obtained 15874,5 and 2150 so the ratio of $738 \%$ is obtained.

Then the comparison for the MIP methanol and NIP methanol was found that the MIP methanol is $122 \%$ better. The comparison of the MIP with the chloroform solvent and the MIP methanol solvent obtained that the MIP desorption by the chloroform is $602 \%$ better because the chloroform is the porogen solvent used for the occurrence of polymerization so it will give re-bonding with good results ${ }^{(6)}$. For ethyl acetate, it is obtained that the MIP and NIP both of them desorp $100 \%$.

\section{CONCLUSION}

The DMAA interaction with 1:6 functional monomers interacts in the hydrogen bond. The Gibbs-free energy obtained is $-5.434 \mathrm{j} / \mathrm{mol}$. The MIP and the NIP using functional monomers of methacrylic acid and the DMAA as the template molecule ratio of 1:6:20 can be synthesized using direct heating method. The resulting MIP has greater selectivity compared to the NIP, with the adsorption capacity percentage of $235 \%$ and the percentage of desorption capacity for 
the MIP and NIP chloroform of $738 \%$ and $122 \%$. The MIP of chloroform to the MIP methanol had better percentage of chloroform solvent $602 \%$.

\section{ACKNOWLEDGEMENTS}

The research was supported by Grant of Scientific Research and Innovation Group, Bandung Institute of Technology 2017.

\section{REFERENCES}

1. WADA. The Prohibit List. The World Anti Doping Code. https://www.wada-ama.org/sites/default/files/ resources/files/wada_anti-doping_code_2009_en_0. pdf. Accessed : Februari 6, 2017 .2010.

2. Zhang Y, Woods, RM, Breitbach ZS, and Amstrong DW. 1,3-Dimethylamylamine (DMAA) in suplements and geranium products: Natural or synthetic? Drug testing and analisis. 2012. www.drugtestinganalysis. com DOI 10.1002/dta.1368.

3. Vasapollo G, Sole RD, Mergola L, Lazzoi MR, Scardino A, Scorrano S, Mele G.. Molecularly imprinted polymers: present and future prospective. Int. J. Mol. Sci 12. 2011. 5908-45

4. Hasanah AN. Sintesis dan karakterisasi sorben hasil teknik molecular imprinted polymer untuk ekstraksi fase padat obat antidiabetes golongan sulfonil urea dalam matriks biologi [Disertasi]. Bandung: Sekolah Farmasi Institut Teknologi Bandung, Prodi Doktor Farmasi. 2015. 34.

5. Anita. Model matematis penjerapan kadmium dalam air pada adsorben kulit nangka. Prosiding Seminar. 2015. 81-6.

6. Lorenzo CA, Concheiro A. Handbook of moleculary imprinted polymers. United Kingdom : Smithers Rapra Group. 2013. 87-90.

7. Fillaeli A. Applications of molecularly imprinted polymer in separation and analytical chemistry. Dalam: Proceeding of International Conference On Reserach, Implementation And Education of Mathematics and Sciences, Yogyakarta 17 - 19 Mei, 2015:C11-18.

8. Yan H, Row KH. Characteristic and synthetic approach of molecularly imprinted polymer. Int J Mol Sci. 2006. $155-78$.

9. Royani I. Pembuatan polimer MIP (Molecularly Imprinted Polymer) atrazin untuk diaplikasikan sebagai material sensor. Prosiding Seminar Nasional Material. 2012. 77-9.

10. Utari U. Sintesis polimer tercetak molekul sudan III untuk pemisahan dan analisis dalam kosmetik perona pipi [Skripsi]. Bandung: Prodi Sains dan Teknologi Farmasi ITB; 2017. 15-27.

11. Purnomo H. Kimia komputasi: molekular docking Plants [Protein-Ligand-Ant-System]. Yogyakarta: Pustaka Pelajar. 2013. 13-63. 